\title{
MORFOGENESIS EKSPLAN TUNAS Eucalyptus pellita F. MUELL SECARA IN VITRO PADA MEDIA MURASHIGE AND SKOOG DENGAN ZAT PENGATUR TUMBUH BENZIL AMINO PURIN
}

\author{
(Plant morphogenesis from shoot explant of Eucalyptus pellita F. Muell \\ by in vitro technique in MS Medium with Benzil Amino Purin plant growth regulator) \\ Ellok Dwi Sulichantini $^{1}$, Eliyani ${ }^{1}$, Alvera Prihatini Dewi Nazari ${ }^{1}$ \\ Jurusan Agroekoteknologi Fakultas Pertanian Universitas Mulawarman \\ Jl. Pasir Balengkong, Kampus Gunung Kelua, Samarinda \\ Corresponding author e-mail: ellokds@gmail.com.
}

Article Submitted: $27-08-2020$

Article Accepted : 16-09-2020

\begin{abstract}
Eucalyptus pellita is a fast growing species and has many advantages such as pulp and paper industry raw material, building construction, charcoal, and medicine. The research was carried out to study plant morphogenesis from shoot explant of E. pellita $\mathrm{F}$. Muell by in vitro technique. The experiment was conducted at Tissue Culture Laboratory, Agriculture Faculty of Mulawarman University from March until June 2016. A single-factor experiment was arranged in a Completely Randomized Design with 10 replications. The factor was BAP concentrations (B) consisted of $1.00 \mathrm{mg} \mathrm{BAP} \mathrm{L}^{-1}\left(\mathrm{~b}_{1}\right) ; 2.00 \mathrm{mg} \mathrm{BAP} \mathrm{L}^{-1}\left(\mathrm{~b}_{2}\right) ; 3.00 \mathrm{mg} \mathrm{BAP} \mathrm{L}^{-1}\left(\mathrm{~b}_{3}\right)$; and 4,00 mg BAP $L^{-1}\left(b_{4}\right)$. The explants were inoculated on MS medium supplemented with BAP according to the treatments. Data analyzed by analysis of variance (ANOVA) and continued by Least Significant Difference (LSD) test with a level of 5\%. The results of the experiment showed that the BAP concentrations can promote shoot formation of E. pellita. Statistical analysis indicated that the effect of BAP concentrations significantly different on the number of shots at 8 weeks after inoculation (WAI), shoot length, and several leaves at 4; 6; and 8 WAI, however, it's no significant difference on shoot formation time and several shots at 4 and 6 WAI. The highest number of shoots, shoot length, and several leaves achieved by $4,00 \mathrm{mg} \mathrm{BAP} \mathrm{L}^{-1}$.
\end{abstract}

Keywords: Eucalyptus pellita, BAP, in vitro

\section{PENDAHULUAN}

Eucalyptus pellita merupakan tanaman yang cepat tumbuh dan tidak menuntut persyaratan yang tinggi terhadap tempat tumbuhnya, mempunyai banyak manfaat yaitu untuk bahan pembuatan rumah, jembatan, bantalan kereta api, kapal, furniture, kayu bakar, arang, dan bahan baku industri pulp (Anonim, 1994; Anonim, 2013). Hardwood, (1998) dan Widyana dkk, (2000) menambahkan, selain sebagai bahan baku pulp dan kertas, kayu Eucalyptus digunakan untuk konstruksi bangunan dan telah lama dipergunakan untuk industri arang di Brazil, sehingga menjadikannya sebagai tanaman yang bernilai ekonomi tinggi. Sampai saat ini, bahan baku industri pulp belum mencukupi, oleh karena itu peningkatan mutu dan hasil E. pellita terus dilakukan dalam program pemuliaan tanaman. Agar diperoleh keturunan yang sama dengan induknya, maka tanaman hasil pemuliaan perlu diperbanyak secara vegetatif, salah satu diantaranya adalah dengan teknik kultur jaringan. 
Teknik kultur jaringan mempunyai keunggulan dibandingkan teknik perbanyakan vegetatif yang lain, yaitu dapat memperbanyak tanaman dalam jumlah besar dalam waktu singkat, sehingga sangat berguna untuk memperbanyak material unggul yang langka dan berumur panjang, serta menghasilkan keturunan yang sama dengan induknya. Keberhasilan perbanyakan secara vegetatif tergantung antara lain pada juvenilitas pohon induk. Semakin muda pohon induk, tingkat regenerasinya semakin tinggi. Tingkat juvenilitas tanaman dapat dipertahankan melalui perbanyakan berseri, pemangkasan, subkultur beberapa kali, dan penyimpanan jaringan (Bonga dan Aderkas, 1993; Talbert et al., 1993; Haapala et al, 2004).

Perbanyakan secara kultur jaringan telah berhasil dilakukan pada Eucalyptus species maupun hybrid. Kultur jaringan $E$. pellita telah berhasil dilakukan dengan menggunakan ruas batang (nodal segment) dan ditanam pada media yang mengandung auksin dan sitokinin (Brondani et al, 2011). Eksplan yang telah digunakan pada berbagai spesies Eucalyptus adalah kotiledon, hipokotil dan potongan bagian-bagian daun (Nugent et al, 2001; Quoirin dan Quisen, 2006; Brondani et al, 2011).

Pada kultur jaringan, morfogenesis suatu eksplan sangat dipengaruhi oleh keseimbangan zat pengatur tumbuh auksin dan sitokinin. Salah satu jenis sitokinin yang dipakai untuk regenerasi E. pellita adalah Benzil Amino Purine (BAP).

Salisbury dan Ross

mengemukakan bahwa sitokinin merupakan zat pengatur tumbuh yang mendorong pembelahan sel (sitokinesis) dan pembentukan organ, menunda penuaan dan meningkatkan aktivitas wadah penampung hara, memacu perkembangan kuncup samping tumbuhan dikotil, memacu pembesaran sel pada kotiledon dan daun tumbuhan dikotil, serta memacu perkembangan kloroplas dan sintesis klorofil. Dewi (2008) menambahkan, sitokinin memacu pembelahan sel, pertumbuhan tunas, mengaktifkan gen, serta aktivitas metabolik secara umum, namun pada saat yang sama, sitokinin menghambat pembentukan akar. Pada kultur jaringan, sitokinin dapat meningkatkan pembelahan, pertumbuhan dan perkembangan kultur sel tanaman. Secara umum, konsentrasi sitokinin yang dipakai antara 0,10 sampai $10,00 \mathrm{mg} \mathrm{L}^{-1}$.

Benzil Amino Purine (BAP) merupakan sitokinin sintetik yang mempunyai struktur serupa dengan kinetin dan berdasarkan hasil pengujian Skoog, Leonard dan kawan-kawan dengan kalus tembakau, turunan-turunan adenin yang disubstitusi pada posisi 6 , seperti BA, adalah yang paling aktif sebagai sitokinin (Wattimena, 1988).

Penelitian bertujuan untuk mengetahui morfogenensis eksplan tunas $E$. pellita secara in vitro.

\section{METODE PENELITIAN}

Penelitian dilaksanakan di Laboratorium Kultur Jaringan Fakultas Pertanian Universitas Mulawarman Samarinda.

Bahan yang digunakan terdiri atas eksplan tunas E. pellita, ZPT Benzil Amino Purin (BAP), media Murashige dan Skoog (MS), bahan-bahan sterilisasi (Dithane M45, Bayclin, Sunlight cair, Betadin, Tween20, alkohol 90\%, alkohol 70\% dan spiritus), tissue, kapas, plastic wrap, plastik gulung dan karet gelang.

Alat yang dipakai terdiri atas autoclave, laminar air flow cabinet, botol kultur, timbangan analitik, $\mathrm{pH}$ meter/pH indicator, alat-alat bedah, hot plate, kompor gas, gelas ukur, botol erlenmeyer dan petridish.

Percobaan menggunakan Rancangan Acak Lengkap dengan faktor tunggal yaitu konsentrasi BAP (B) dengan 10 ulangan. Perlakuan terdiri atas : $1,00 \mathrm{mg} \mathrm{BAP} \mathrm{L}^{-1}$ $\left(b_{1}\right) ; 2,00 \mathrm{mg} \mathrm{BAP} \mathrm{L}^{-1}\left(\mathrm{~b}_{2}\right) ; 3,00 \mathrm{mg} \mathrm{BAP} \mathrm{L}$ ${ }^{1}\left(\mathrm{~b}_{3}\right) ; 4,00 \mathrm{mg} \mathrm{BAP} \mathrm{L}^{-1}\left(\mathrm{~b}_{4}\right)$. Setiap ulangan 
terdiri dari lima eksplan, sehingga total eksplan yang dipakai sebanyak $4 \times 10 \times 5=$ 200 eksplan.

Eksplan tunas disterilisasi menggunakan fungisida dan Bayclin, selanjutnya dibilas dengan air steril. Eksplan steril dipotong-potong di dalam laminar air flow dan ditanam pada media dasar MS yang ditambah ZPT BAP sesuai perlakuan. Selanjutnya kultur diinkubasi pada ruang kultur bersuhu $25-28^{\circ} \mathrm{C}$. Selama periode inkubasi, kultur diinkubasi pada kondisi terang selama 24 jam, sedangkan subkultur dilakukan setiap empat minggu.

Pengamatan dilakukan setiap dua minggu sampai akhir pengamatan. Data yang dikumpulkan terdiri atas : waktu tunas terbentuk, jumlah tunas, panjang tunas, dan jumlah daun.

Sidik ragam dilakukan untuk mengetahui pengaruh konsentrasi BAP, apabila hasil sidik ragam menunjukkan pengaruh yang berbeda nyata, untuk membandingkan antara dua rata-rata perlakuan dilakukan uji Beda Nyata Terkecil (BNT) pada taraf 5\%.

\section{HASIL DAN PEMBAHASAN}

Hasil sidik ragam menunjukkan bahwa pengaruh konsentrasi BAP berbeda sangat nyata terhadap jumlah tunas umur 8 MSI, panjang tunas umur 4 dan 6 minggu setelah inokulasi (MSI) dan jumlah daun pada umur 6 dan 8 MSI; berbeda nyata terhadap panjang tunas umur 8 MSI, dan jumlah daun pada umur $4 \mathrm{MSI}$; tetapi berbeda tidak nyata terhadap waktu tunas terbentuk dan jumlah tunas umur 4 dan 6 MSI. Hasil penelitian menunjukkan bahwa penambahan BAP dengan konsentrasi 1,00; 2,00; 3,00; dan 4,00 mg BAP L ${ }^{-1}$ pada media kultur MS mampu menginduksi tunas $E$. pellita (Tabel 1)

Rekapitulasi data hasil penelitian morfogenesis eksplan tunas E. pellita secara in vitro disajikan pada Tabel 1.

Tabel 1. Rekapitulasi Data Hasil Penelitian Morfogenesis Eksplan Tunas E. pellita

\begin{tabular}{|c|c|c|c|c|c|c|c|c|c|c|}
\hline \multirow{2}{*}{$\begin{array}{l}\text { Konsentrasi } \\
\text { BAP } \\
\text { Concentratio } \\
\text { ns of BAP } \\
\left(\mathrm{mg} \mathrm{L}^{-1}\right)\end{array}$} & \multirow{2}{*}{$\begin{array}{c}\text { Waktu } \\
\text { tunas } \\
\text { muncul } \\
\text { Shoot } \\
\text { formati } \\
\text { on time } \\
\text { (DAI) }\end{array}$} & \multicolumn{3}{|c|}{$\begin{array}{c}\text { Jumlah tunas } \\
\text { Number of shoots } \\
\text { (shoot) }\end{array}$} & \multicolumn{3}{|c|}{$\begin{array}{l}\text { Panjang tunas } \\
\text { Shoot length } \\
(\mathrm{cm})\end{array}$} & \multicolumn{3}{|c|}{$\begin{array}{c}\text { Jumlah daun } \\
\text { Number of leaves } \\
\text { (sheet) }\end{array}$} \\
\hline & & $\begin{array}{c}4 \\
\text { MSI }\end{array}$ & $\begin{array}{c}6 \\
\text { MSI }\end{array}$ & $\begin{array}{c}8 \\
\text { MSI }\end{array}$ & $\begin{array}{c}4 \\
\text { MSI }\end{array}$ & $\begin{array}{c}6 \\
\text { MSI }\end{array}$ & $\begin{array}{c}8 \\
\text { MSI }\end{array}$ & $4 \mathrm{MSI}$ & $6 \mathrm{MSI}$ & $8 \mathrm{MSI}$ \\
\hline & HSI & \multicolumn{3}{|c|}{....... tunas ....... } & \multicolumn{3}{|c|}{ 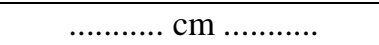 } & \multicolumn{3}{|c|}{ helai ............ } \\
\hline & tn & $\operatorname{tn}$ & tn & $* *$ & $* *$ & $* *$ & $*$ & $*$ & $* *$ & $* *$ \\
\hline 1,00 & 15,80 & 1,00 & 1,50 & $1,50^{\mathrm{a}}$ & $1,00^{\mathrm{a}}$ & $1,75^{\mathrm{a}}$ & $2,40^{\mathrm{a}}$ & $1,20^{\mathrm{a}}$ & $2,40^{\mathrm{a}}$ & $2,40^{\mathrm{a}}$ \\
\hline 2,00 & 15,30 & 1,00 & 1,60 & $1,90^{\mathrm{a}}$ & $1,30^{\mathrm{b}}$ & $1,85^{\mathrm{abc}}$ & $2,50^{\mathrm{ab}}$ & $1,40^{\mathrm{b}}$ & $2,80^{\mathrm{a}}$ & $3,20^{\mathrm{b}}$ \\
\hline 3,00 & 15,00 & 1,20 & 1,60 & $2,40^{\mathrm{b}}$ & $1,40^{\mathrm{b}}$ & $2,05^{\mathrm{bc}}$ & $2,60^{\mathrm{ab}}$ & $2,00^{\mathrm{c}}$ & $4,00^{b}$ & $4,80^{c}$ \\
\hline 4,00 & 14,60 & 1,30 & 2,00 & $2,60^{\mathrm{b}}$ & $1,45^{\mathrm{b}}$ & $2,20^{\mathrm{c}}$ & $2,70^{\mathrm{b}}$ & $2,20^{\mathrm{d}}$ & $4,80^{\mathrm{b}}$ & $5,40^{\mathrm{d}}$ \\
\hline $\mathrm{KK}(\%)$ & 4,35 & 9,00 & 10,95 & 22,73 & 21,37 & 13,36 & 2,30 & 21,83 & 10.70 & 24,60 \\
\hline
\end{tabular}

Keterangan: Angka rata-rata yang diikuti oleh huruf yang sama pada kolom menunjukkan berbeda nyata pada uji BNT 5\%. tn $=$ pengaruh konsentrasi $\mathrm{BAP}$ berbeda tidak nyata; $*=$ pengaruh konsentrasi $\mathrm{BAP}$ berbeda nyata; $* *=$ pengaruh konsentrasi BAP berbeda sangat nyata.

Penambahan BAP dengan konsentrasi yang dipakai menunjukkan pengaruh yang berbeda tidak nyata terhadap waktu tunas terbentuk (Tabel 1), walaupun ada kecenderungan semakin tinggi konsentrasi yang dipakai, waktu tunas terbentuk semakin cepat (Gambar 1). 


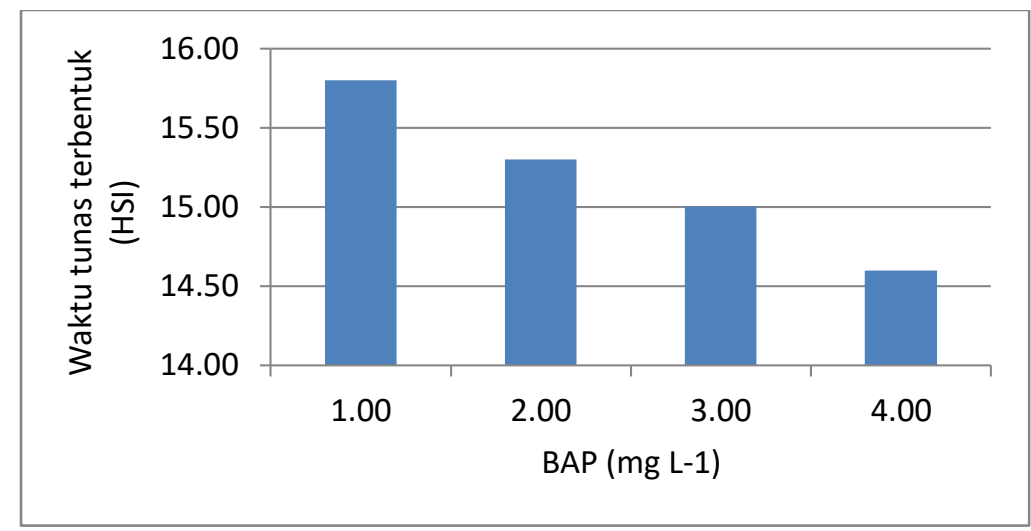

Gambar 1. Pengaruh konsentrasi BAP terhadap waktu tunas E. pellita terbentuk

Terbentuknya tunas E. pellita menunjukkan bahwa umur eksplan mempengaruhi kemampuan regenerasi sel sebagaimana dilaporkan oleh Sulichantini (1998) pada penelitian induksi embrio somatik dari beberapa tipe eksplan pada beberapa kultivar kacang tanah, bahwa semakin muda umur eksplan, regenerasinya akan semakin tinggi.

Pengamatan terhadap jumlah tunas menunjukkan pengaruh konsentrasi BAP berbeda tidak nyata pada umur 4 dan 6 MSI, tetapi berbeda sangat nyata pada umur 8 MSI. Ada kecenderungan semakin tinggi konsentrasi BAP, semakin banyak jumlah tunas yang terbentuk (Gambar 2). Pembentukan tunas adalah hasil pembelahan, pembesaran, dan diferensiasi sel, proses-proses tersebut sangat dipengaruhi oleh ketersediaan zat pengatur tumbuh, diantaranya sitokinin. Salisbury dan Ross (1995) mengemukakan bahwa pertumbuhan dan perkembangan sel dihasilkan dari tiga peristiwa yang sederhana, yaitu pembelahan, pembesaran, dan diferensiasi sel. Sitokinin merupakan zat pengatur tumbuh yang mendorong pembelahan sel (sitokinesis) dan pembentukan organ. Dewi (2008) menambahkan, sitokinin memacu pembelahan sel, pertumbuhan tunas. Pada kultur jaringan, sitokinin dapat meningkatkan pembelahan, pertumbuhan dan perkembangan kultur sel tanaman. Secara umum, konsentrasi sitokinin yang dipakai antara 0,10 sampai $10,00 \mathrm{mg} \mathrm{L}^{-1}$. Pada umur 4 dan 6 MSI, pengaruh konsentrasi BAP tidak berbeda secara nyata terhadap jumlah tunas disebabkan pada umur 4 dan 6 MSI, konsentrasi BAP yang diberikan belum mampu memacu pembelahan sel secara nyata.

Jumlah tunas pada umur 8 MSI dipengaruhi sangat nyata oleh konsentrasi BAP (Tabel 1). Semakin lama waktu inkubasi, pengaruh konsentrasi BAP akan semakin nyata berbeda. Hal ini disebabkan 8 minggu setelah inokulasi, konsentrasi BAP yang terakumulasi pada eksplan mencapai kadar yang cukup untuk memacu pembelahan sel secara nyata. 


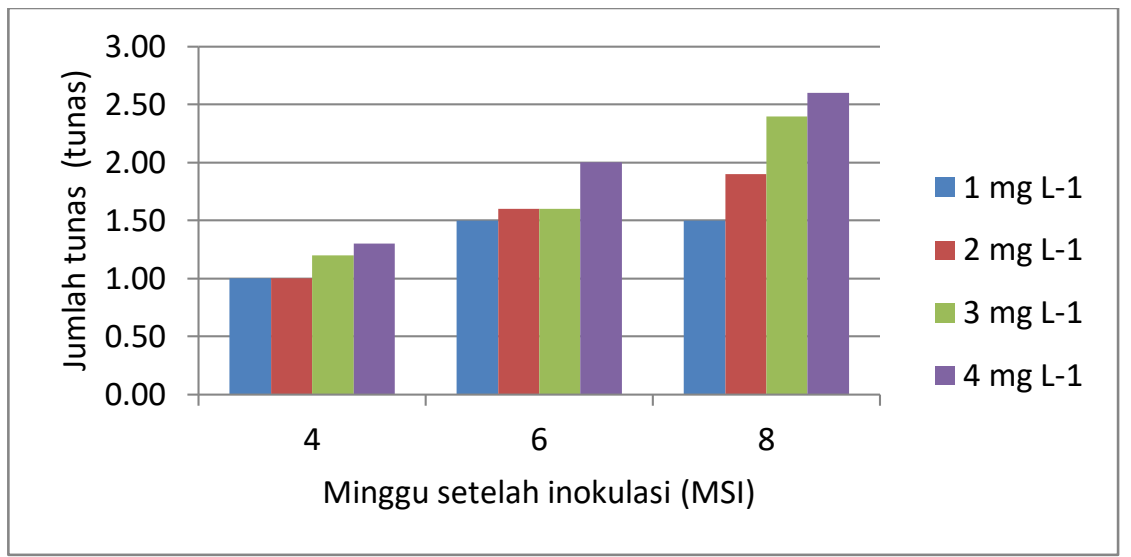

Gambar 2. Pengaruh konsentrasi BAP terhadap jumlah tunas E. Pellita

Hasil penelitian menunjukkan bahwa panjang tunas dan jumlah daun dipengaruhi secara nyata oleh konsentrasi BAP pada semua umur pengamatan (Tabel 1). Penambahan BAP pada media MS mampu mendorong pembelahan sel dan pembentukan organ meskipun tanpa penambahan IAA pada media kultur yang dipakai, sehingga selain memacu pembentukan tunas dan daun, BAP akan memacu pemanjangan tunas dan memperbanyak jumlah daun E. pellita (Gambar 3 dan 4).

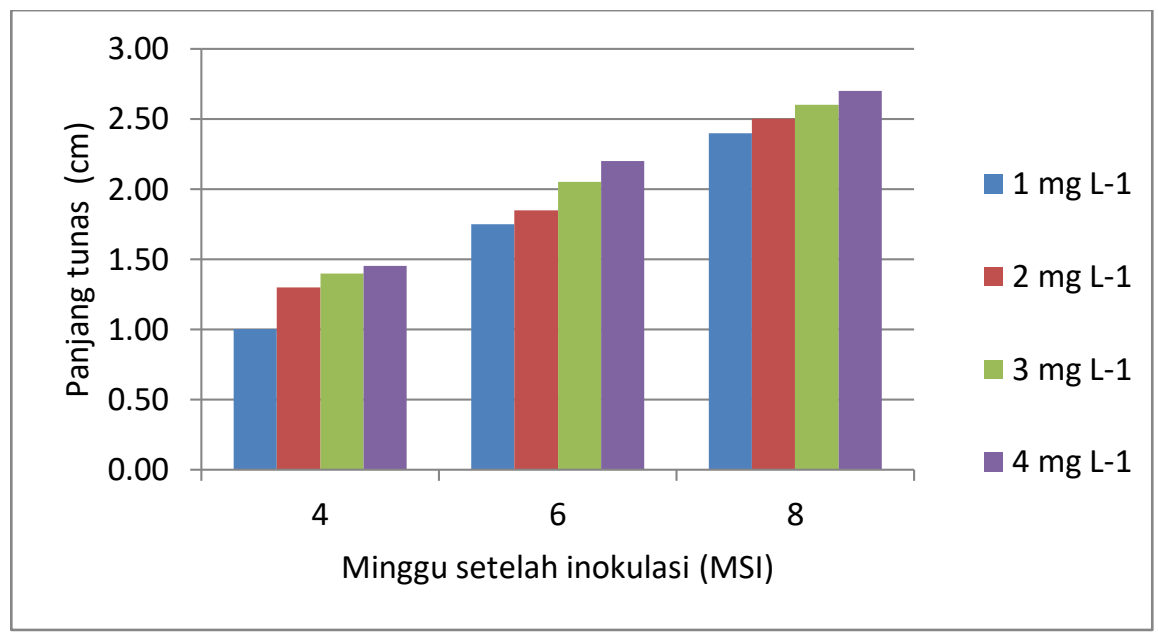

Gambar 3. Pengaruh konsentrasi BAP terhadap panjang tunas E. pellita

Hal ini sesuai dengan pendapat Salisbury dan Ross (1995) bahwa sitokinan merupakan zat pengatur tumbuh yang mendorong pembelahan sel (sitokinesis) dan pembentukan organ. Dewi (2008) menambahkan, sitokinin memacu pembelahan sel, pertumbuhan tunas, mengaktifkan gen, serta aktivitas metabolik secara umum. Pada kultur jaringan, sitokinin dapat meningkatkan pembelahan, pertumbuhan dan perkembangan kultur sel tanaman.

Pembelahan sel merupakan salah satu diantara tiga tahap pertumbuhan dan perkembangan sel. Pembelahan menyebabkan jumlah sel bertambah banyak, diikuti dengan pembesaran, yaitu sel yang terbentuk membesar volumenya, sehingga terjadi peningkatan ukuran, dan terakhir adalah diferensiasi sel, yaitu sel yang telah 
mencapai ukuran maksimum akan terspesialisasi menjadi berbagai jaringan dan organ sebagaimana dinyatakan oleh Salisbury dan Ross (1995), bahwa pertumbuhan dan perkembangan sel dihasilkan dari tiga peristiwa yang sederhana, yaitu pembelahan, pembesaran, dan diferensiasi sel.

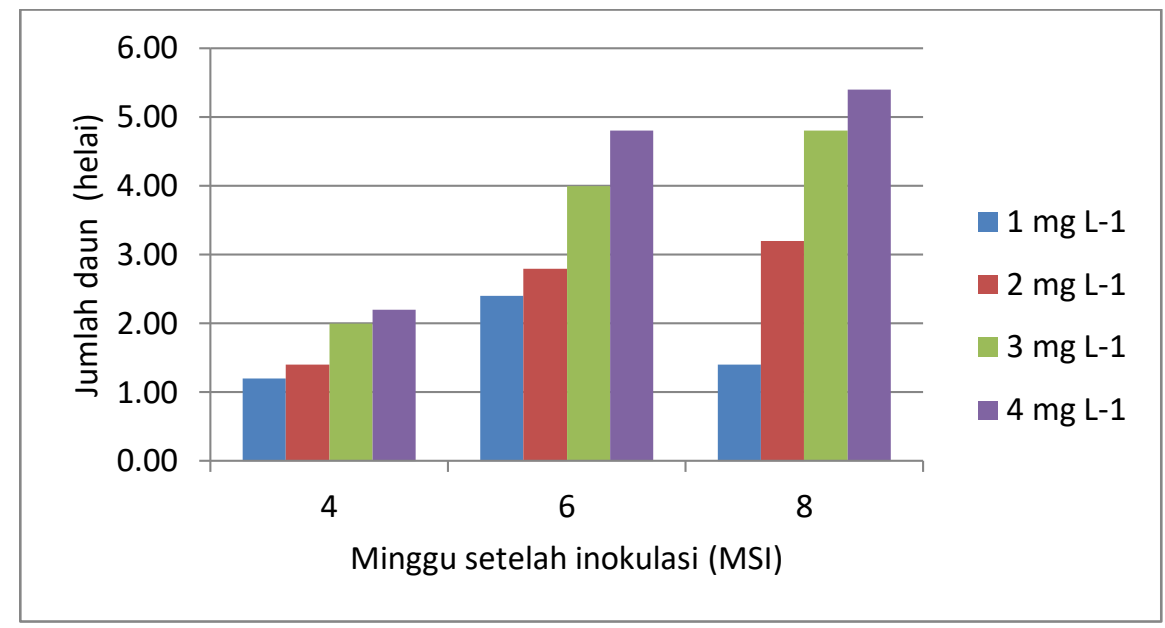

Gambar 4. Pengaruh konsentrasi BAP terhadap jumlah daun E. pellita

Benzil Amino Purine termasuk golongan sitokinin sintetik yang paling aktif memacu pembelahan sel, sebagaimana diungkapkan oleh Wattimena (1988) bahwa BA (BAP) mempunyai struktur yang serupa dengan kinetin dan berdasarkan hasil pengujian Skoog, Leonard dan kawankawan dengan kalus tembakau, turunanturunan adenin yang disubstitusi pada posisi 6 , seperti BA, adalah yang paling aktif sebagai sitokinin.

Konsentrasi BAP yang dipakai pada penelitian ini berada pada kisaran yang dianjurkan sebagaimana dinyatakan oleh Dewi (2008), secara umum, konsentrasi sitokinin yang dipakai antara 0,10 sampai $10,00 \mathrm{mg} \mathrm{L}^{-1}$.

\section{KESIMPULAN DAN SARAN}

\section{Kesimpulan}

Berdasarkan hasil penelitian dapat ditarik kesimpulan sebagai berikut :

1. Penambahan BAP secara tunggal dengan konsentrasi 1,00; 2,00, 3,00; dan 4,00 $\mathrm{mg} \mathrm{L}^{-1}$ mampu menginduksi tunas Eucalyptus pellita.
2. Konsentrasi $4,00 \quad \mathrm{mg}$ BAP $\mathrm{L}^{-1}$ memberikan hasil terbaik terhadap jumlah tunas, panjang tunas, dan jumlah daun E. pellita.

\section{Saran}

Berdasarkan hasil penelitian dapat dikemukakan saran yaitu perlu dilakukan penelitian lebih lanjut mengenai konsentrasi BAP maupun kombinasi BAP dengan IAA menggunakan berbagai tipe eksplan terhadap regenerasi E. pellita.

\section{DAFTAR PUSTAKA}

Anonim. 1994. Pedoman Teknis Penanaman Jenis-Jenis Kayu Komersial. Badan Litbang Departemen Kehutanan, Jakarta.

Anonim. 2013. Species information. http://worldagroforestry.org.

Diakses pada tanggal 5 Januari 2012.

Bonga, J.M. and P. Von Aderkas. 1993. Rejuvenation of tissue from mature conifers and its implications for 
propagation in vitro. In Ahuja M.R. and W.J. Libby (eds.). Clonal Forestry: Genetics and Biotechnology. Springer-Verlag, Berlin.

Brondani, G.E., L.F. Dutra, J. Wendling, F. Grossi, F.A. Hansel, and M.A. Araujo. 2011. Micropropagation of an Eucalyptus hybrid (Eucalyptus benthamii $\mathrm{x}$ Eucalyptus dunnii). Acta Sci. Agron. 33 (4): 20-27.

Dewi, I.R. 2008. Peranan dan Fungsi Fitohormon bagi Pertumbuhan Tanaman. Fakultas Pertanian Universitas Padjajaran, Bandung.

Haapala, T., A. Pakkanen and P. Pulkkinen. 2004. Variation in survival and growth of cuttings in two clonal propagation methods for hybrid Aspen (Papua tremula_P. tremuloides). Forest Ecology and Management 193: 345-354.

Hardwood, C. 1998. Eucalyptus pellita-an annotated bibliography. CSIRO Publishing: Collingwood, Victoria.

Nugent, G., S.F. Chandler, P. Whiteman, T.W. Stevenson. 2001. Adventitious bud induction in Eucalyptus globulus Labill. Vitro Cell Dev. Biol_Plant. 37: 388-391. DOI: $10.1007 / \mathrm{s} 11627-$ 001-0068-0. Diakses tanggal 6 Januari 2012.

Quoirin, M. And R. Quisen. 2006. Advance in Genetic Transformation of
Eucalyptus Species. Molecular Biology of Tropical Plants. pp. 4156.

Salisbury, F.B. dan C.W. Ross. 1995. Fisiologi Tumbuhan Jilid 3 edisi keempat. Terjemahan Diah R. Lukman dan Sumaryono. ITB, Bandung.

Sulichantini, E.D. 1998. Induksi Embrio Somatik dari Beberapa Tipe Eksplan Beberapa Kultivar Kacang Tanah (Arachis hypogaea L.). Thesis Program Pascasarjana IPB, Bogor. Tidak diterbitkan.

Talbert, C.B., G.A. Ritchie and P. Gupta. 1993. Conifer vegetative propagation an overview from a commercialization prospective. In Ahuja M.R. and W.J. Libby (eds.). Clonal Forestry I: Genetics and Biotechnology. Springer-Verlag, Berlin.

Wattimena, G.A. 1988. Zat Pengatur Tumbuh Tanaman. PAU IPB bekerja sama dengan Lembaga Sumberdaya Informasi-IPB, Bogor.

Widyana, Y., M. Na'iem dan S. Danarto, 2000. Studi pendahuluan fenologi pembungaan Eucalyptus pellita F. Muell di Wanagama I Gunung Kidul, Yogyakarta. Prosiding Seminar Nasional Status Silvikultur 1999. E.B. Hardiyanto (ed.) Fakultas Kehutanan UGM, Yogyakarta. 